\title{
Effect of Feeding Graded Levels of Wild Silver Leaf Desmodium (Desmodium uncinatum) on Feed Intake and Digestibility of Horro Sheep Fed A Basal Diet of Natural Pasture Hay
}

\author{
Jalel Fikadu $^{1}$ Dr. Mangistu Urge ${ }^{2}$ \\ 1. Assosa University, College of Agriculture and Natural Resources, PO. Box18, Assosa, Ethiopia \\ 2. Haramaya University, College of Agriculture and Environmental Sciences P.O. Box137, Diredawa, Ethiopia
}

\begin{abstract}
This experiment was conducted at Nedjo ATVET College with the objective of evaluating the effects of graded levels of wild silver leaf desmodium (Desmodium uncinatum) on feed intake, and digestibility, of Horro sheep fed a basal diet of natural pasture hay. Twenty intact male Horro sheep with intact milk teeth and an average initial weight of $18.28 \pm 1.47 \mathrm{~kg}$ (mean \pm SD) were used. The experiment consisted of 7 days of digestibility trial and 90 days of feeding trials. The experimental sheep were blocked into 5 blocks of 4 animals based on initial body weight and randomly assigned to one of the four treatments within a block. The treatments were natural pasture hay ad libitum $\left(\mathrm{DU}_{1}\right)$ and wild silver leaf desmodium supplement at levels of $200\left(\mathrm{DU}_{2}\right), 300\left(\mathrm{DU}_{3}\right)$, 400(DU $)_{4} \mathrm{~g} / \mathrm{head} / \mathrm{d}$ on dry matter bases. The basal diet had DM, CP and OM of 91.2, 75.5 and 9.3, respectively while the corresponding values for Desmodium were 89.8, 77.8 and 16.8. Total dry matter intake $(698,725.4$, 773.3 and $864 \mathrm{~g} / \mathrm{d}$ in DU-0, DU-200, DU-300 and DU-400 respectively) significantly increased with increasing level of Desmodium supplementation. Significantly higher $(\mathrm{p}<0.001)$ dry matter (DMD) $(48,68,72$ and $80 \%$ in DU-0, $\mathrm{DU}_{-200}, \mathrm{DU}_{-300}$ and DU-400 respectively), organic matter (OM) $(48,70,74$ and $82 \%$ in DU-0, DU-200, DU-300 and DU-400 respectively), and crude protein (CP) $(84,88,88$ and $91 \%$ in DU-0 DU-200 DU-300 and DU-400 respectively) digestibility were noted in this study. In this study among the levels of supplementation, $400 \mathrm{~g}$ wild silver leaf desmodium resulted in betterdry matter intake (DMI), and nutrient digestibility.
\end{abstract}

Keywords: desmodium ,dry matter, Digestibility ,horro sheep

DOI: $10.7176 / \mathrm{JBAH} / 10-1-05$

Publication date: January $31^{\text {st }} 2020$

\section{INTRODUCTION}

Livestock in Ethiopia are an important and integral component of agriculture, which is the backbone of the economy. These sub-sectors does not only provide animal protein for the ever escalating human population, but also contribute in providing export commodities, such as live animals, hides and skins products serving as a source of foreign exchange earning to the country (CSA, 2004). However, productivity is very low and lags behind the growth of the population. This leads to a net decline in per capita consumptions of livestock products. The average per capita annual consumption of meat and dairy products are just $4.6 \mathrm{~kg}$ and $16.7 \mathrm{~kg}$, respectively (Kibrom and Ibrahim 2012 ). Given the recent growth in income, there is potential for growth in the demand for livestock products. This requires increased livestock production and productivity in the future.

Sheep are an important part of the livestock sector and their socio-economic importance is widely recognized. Ethiopia has a sheep population of 29.5 million that are distributed from arid to highland areas of the country (CSA, 2018). In Ethiopia, extensive sheep production under traditional communal grazing or browsing system is widely practiced. Sheep from this system provide more than $30 \%$ of all the domestic meat consumption and generate cash income from exports of meat, live animals and skins (Zelalem and Fletcher, 1991). However, the productivity level of sheep is very low. The carcass yield per animal slaughtered is estimated to be about $10 \mathrm{~kg}$ of mutton (FAO, 2000). Although, there are various and complex constraints that contributes to these reduced productivity of sheep, the most important limiting factor is feed scarcity. In addition to this, sheep productivity is also constrained by diseases, inadequate utilization of indigenous sheep breeds, lack of infrastructure, market information and trained personnel (Markos, 2006).

Livestock in Ethiopia derive most of their feed from natural pasture and crop residues. Most of the roughages found in the tropics are generally deficient in nitrogen, energy or some others minerals. Therefore, they can't adequately support growth and milk production in ruminants (Ash, 1990; Gary and Gupta, 1992; Seyoum and Zinash 1995). The ever increasing human population has also caused conversion of range/pasturelands into croplands leading to reduced land for grazing and fodder production. Therefore, improving the existing feed resource by identifying alternative and more nutritious feeds have been the interest of research in order to bridge the gap between the requirement and availability of nutrients. Conventional concentrate supplements are costly and in short supply in developing countries (Anderson, 1987). Thus improvement in the availability of feed recourses could be achieved through cultivation of high quality forages with high yield and adapted to local conditions, such as silvery leaf desmodium (Desmodium uncinatum) which 
are being widely promoted for adoption in Ethiopia (Tessema and Halima, 1998). Supplementation with leguminous forages that can be grown on the farm appears to be a more feasible alternative to improve the feeding value of fibrous roughage such as natural pasture hay, since they fail to provide rumen micro-organisms with the required nutrients (Devendra, 1985). In this context, $\mathrm{N}$ content of lower than 1.2\% may impair rumen function and leads to reduced feed intake and animal performance (Conrad and Hibb, 1968).

Legumes can contribute to a better utilization of natural pasture hay. They are rich in protein (both fermentable and by-pass protein depending upon the level of tannin content) and other nutrients such as minerals. The amount of forage legumes needed to provide effective supplementation could vary with the quality of the basal diet and the quality of the supplement. In the present study area, wild desmodium (Desmodium uncinatum cv. Silver leaf) is naturally gown and is widely used by farmers as feed resource for animals either as grazing or hay forage. However, the nutritive value and its digestibility of this forage has not been evaluated for its proper utilization. The present study was therefore designed with the following objectives.

\section{Objective of the study}

$>\quad$ to evaluate feed intake and digestibility of Horro sheep fed a basal diet of natural pasture hay and supplemented with graded levels of Silver leaf desmodium (Desmodium uncinatum)

\section{MATERIALS AND METHODS}

\section{Experimental Design and Treatments}

The experimental design was randomised complete block design (RCBD) that consists of four treatments. The treatments were supplementation of graded levels of wild silver leaf desmodium to natural pasture hay. The animals were blocked based on initial live weight into five blocks of four animals per block. The four treatments were randomly assigned to each experimental animal in a block for three months(90days). The experimental design used is therefore, completely randomized block design.

\section{Experimental treatments \\ DU1= Natural pasture hay ad libitum \\ DU2=Natural pasture hay ad libitum $+200 \mathrm{~g}$ Desmodium uncinatum \\ DU3 = Natural pasture hay ad libitum $+300 \mathrm{~g}$ Desmodium uncinatum \\ DU4= Natural pasture hay ad libitum $+400 \mathrm{~g}$ Desmodium uncinatum}

\section{Digestibility Trial}

Digestibility experiment was conducted at the beginning following the 15 days of adaptation period using all animals in the treatment. The digestibility trial was conducted for 10 days during which animals were acclimatized to carrying of the faecal collection bag for three days, followed by 7 days of total faeces collection. The faecal output per animal was collected each morning and weighed. Twenty percent of the daily faecal excretion was sampled after thorough mixing and pooled over the experimental period. Daily collected faecal samples were stored frozen at $-20^{\circ} \mathrm{C}$. After seven days of total faecal collection period, samples taken daily from each animal was thoroughly mixed and sub-sampled. The faecal samples were dried in an oven at $60{ }^{\circ} \mathrm{C}$ for 72 hours. Dried samples were ground to pass through a $1 \mathrm{~mm}$ sieve and preserved for further chemical analysis. Feed samples from each feed and refusals from each animal were collected daily during the 7 days of digestibility period. The feed samples were pooled per feed type and refusals per treatment and was used for chemical analysis. The apparent digestibility coefficient (DC) of nutrients was calculated by the formula:

Apparent DM/nutrient digestibility $=\underline{\mathrm{DM} / \text { nutrient intake }-\mathrm{DM} / \text { nutrient in the feces }}$

$\mathrm{DM} /$ nutrient intake

\section{Feed intake}

The feed offered and refused corresponding to each treatment diet from each sheep was recorded daily throughout the experimental period. Daily feed intake of the experimental animals was calculated on DM bases as the difference between the feeds offered and refused. Samples of the feed offered were collected per batch and pooled per feed type during the feeding trial. Refusal samples during the feeding trial were collected for each animal for a week in the middle of the experiment and pooled per treatment. The samples were analyzed for dry matter and nutrients to determine intake of dry matter and nutrients.

\section{Chemical analyses}

Dry matter content of the feed offer was estimated by drying measured quantities of feed samples in a forced draft oven at $105^{\circ} \mathrm{C}$ overnight. Samples of feed offered, refusal, and feces were dried in a forced draft oven at $65^{\circ} \mathrm{C}$ to constant weight to determine partial dry matter content. The samples were then ground to pass through a $1 \mathrm{~mm}$ sieve and stored pending laboratory analysis. All samples of feed and feces were analyzed for DM, ash, 
and $\mathrm{N}$ according to the procedures of AOAC (1990), and Neutral detergent fiber (NDF), acid detergent fiber (ADF) and acid detergent lignin (ADL) according to the procedure of Van Soest and Robertson (1985).

\section{Statistical Analysis}

Data collected was analyzed using the General Linear Model procedure of SAS (SAS, 2008). Treatment means were compared using Tukey adjustment. The model used for data analysis was

$\mathrm{Yij}=\mu+\mathrm{t}_{\mathrm{i}}+\mathrm{b}_{\mathrm{j}}+\mathrm{e}_{\mathrm{ij}}$

Where: $y_{i j}=$ response variable

$$
\begin{gathered}
\mu=\text { overall mean } \\
t_{i}=\text { treatment effect } \\
b_{j}=\text { block effect } \\
\text { eij }=\text { random error }
\end{gathered}
$$

\begin{tabular}{|c|c|c|c|c|c|c|c|}
\hline Parameter & $\% \mathrm{DM}$ & $\% \mathrm{OM}$ & $\% \mathrm{CP}$ & $\% \mathrm{NDF}$ & $\% \mathrm{ADF}$ & $\% \mathrm{ADL}$ & $\% \mathrm{ASH}$ \\
\hline \multicolumn{8}{|l|}{ Feed offered } \\
\hline Hay & 91.2 & 75.5 & 9.3 & 60.8 & 32.6 & 6.2 & 15.7 \\
\hline Desmodium & 89.8 & 77.8 & 16.3 & 57.6 & 32.2 & 9.8 & 12 \\
\hline \multicolumn{8}{|l|}{ Feed refusal } \\
\hline Hay (DU-0) & 90.2 & 80.9 & 6.1 & 65.6 & 35.6 & 6.9 & 9.3 \\
\hline Hay (DU-200g) & 90.1 & 79.4 & 6.4 & 66.6 & 42.6 & 6.8 & 12 \\
\hline Hay (DU-300) & 90.1 & 75.6 & 5.8 & 63.6 & 34.8 & 11 & 15.8 \\
\hline Hay (DU-400) & 90.4 & 74.6 & 6 & 61.8 & 33.8 & 12 & 15.8 \\
\hline Desmodiu (DU-200) & 90.2 & 80.5 & 8.6 & 58.6 & 34.8 & 16 & 9.8 \\
\hline Desmodiu (DU-300) & 90.3 & 70.5 & 11.4 & 59.6 & 36.6 & 14.6 & 14.4 \\
\hline Desmodiu (DU-400) & 90.1 & 75.7 & 12 & 59 & 33.8 & 15.8 & 15.5 \\
\hline
\end{tabular}

RESULTS AND DISCUSSIONS

Chemical Composition of the Experimental Feeds

Table Chemical composition of the experimental feeds (nutrients are as percent dry matter)

\section{Feed Intake}

Table shows the mean daily feed DM and nutrient intakes of Horro sheep fed sole natural pasture hay and graded level of silver leaf desmodium. The mean daily DM intake of hay was significantly higher $(\mathrm{P}<0.001)$ in the non supplemented sheep than the supplemented groups. Among the supplemented sheep, sheep in DU-400g consumed significantly higher amount of hay dry matter than DU-200g and DU-300g. The higher intake of hay in the control treatment as compared to the supplemented ones might be due to the deficiency of nutrients in the hay as a result of which the animals in the control groups thrives to satisfy their nutrients requirement by increasing hay intake. In agreement to the present finding, Mulu (2005) reported higher hay intake in the nonsupplemented (477 g/day) than brewery dried grain supplemented (411-465 g/day) Wogera sheep. Similarly, Fentie (2007) reported that the DM intake of hay in the control treatments was higher $(540.5 \mathrm{~g} /$ day $)$ than for supplemented treatments (366 - $488 \mathrm{~g} /$ day) when Farta sheep fed grass hay basal diet were supplemented with noug seed cake, wheat bran and their mixtures. Total dry matter intake was significantly different among the treatments in the order of DU_0 $<$ DU_ $200 \mathrm{~g}<\mathrm{U}_{-} 300 \mathrm{~g}<$ DU_400g. The increased total DM intake in the present study agreed with the results of Negussie (2008) who noted higher daily total DM intake when the level of desmodium increased in nipper grass based diet. The result of the current study indicated that as the level of desmodium increased, the total DM and OM intake of sheep also increased at least numerically.

The CP intake of DU_400g was significantly higher $(\mathrm{P}<0.001)$ than the other supplemented treatments, which is followed by DU_300g and DU_200g, respectively. Sheep fed the control treatment has a lower CP intake than the supplemented groups. 
Table Daily dry matter and nutrient intake of Horro sheep fed natural pasture hay and graded level of wild silver leaf desmodium.

\begin{tabular}{lllllll}
\hline Parameter & DU-0 & DU.200g & DU.300g & DU-400g & SEM & SL \\
\hline Total DM intake (g/day) & $698.0^{\mathrm{d}}$ & $725.4^{\mathrm{c}}$ & $773.3^{\mathrm{b}}$ & $864.0^{\mathrm{a}}$ & 1.34 & $* * *$ \\
OM intake (g/day) & $517.2^{\mathrm{d}}$ & $540.6^{\mathrm{c}}$ & $594.2^{\mathrm{b}}$ & $662.4^{\mathrm{a}}$ & 1.08 & $* * *$ \\
CP intake (g/day) & $70.8^{\mathrm{d}}$ & $87.9^{\mathrm{c}}$ & $98.3^{\mathrm{b}}$ & $112.0^{\mathrm{a}}$ & 0.09 & $* * *$ \\
NDF intake (g/day) & $415.5^{\mathrm{d}}$ & $423.2^{\mathrm{c}}$ & $456.2^{\mathrm{b}}$ & $513.3^{\mathrm{a}}$ & 0.84 & $* * *$ \\
ADF intake (g/day) & $225.0^{\mathrm{c}}$ & $221.9^{\mathrm{c}}$ & $242.5^{\mathrm{b}}$ & $276.4^{\mathrm{a}}$ & 0.65 & $* * *$ \\
TDDMI (g/d) & $630.7^{\mathrm{d}}$ & $727.0^{\mathrm{c}}$ & $759.0^{\mathrm{b}}$ & $865.6^{\mathrm{a}}$ & 2.40 & $* * *$ \\
TDOMI (g/d) & $453.0^{\mathrm{b}}$ & $466.2^{\mathrm{b}}$ & $584.0^{\mathrm{a}}$ & $663.6^{\mathrm{a}}$ & 43.82 & $* *$ \\
TDCPI (g/d) & $64.7^{\mathrm{d}}$ & $75.6^{\mathrm{c}}$ & $96.8^{\mathrm{b}}$ & $112.1^{\mathrm{a}}$ & 6.17 & $* * *$ \\
TDNDFI (g/d) & $374.4^{\mathrm{d}}$ & $424.3^{\mathrm{c}}$ & $447.6^{\mathrm{b}}$ & $514.3^{\mathrm{a}}$ & 1.54 & $* * *$ \\
TDADFI (g/d) & 199.9 & 178.2 & 200.2 & 277.0 & 26.4 & $*$ \\
\hline
\end{tabular}

$a, b, c,{ }_{\text {means }}$ within rows having different superscript are significantly different; $* *=P<0.01 ; * * *=P<0.001$; $A D F=$ acid detergent fiber; $C P=$ crude protein; DMI=Dry matter intake; TDDMI = Total digestible dry matter intake; TDOMI = Total digestible organic matter intake; TDCPI = Total digestible crude protein intake; $T D N D F I=$ Total digestible neutral detergent fiber intake; TDADFI = Total digestible acid detergent fiber intake; $N D F=$ neutral detergent fiber; $O M=$ organic matter; SEM= standard error of mean; $S L=$ significance level; DU1=natural pasture hay; DU2= natural pasture hay $+200 \mathrm{~g}$ wild silver leaf Desmodium; DU3= natural pasture hay + 300g wild silver leaf Desmodium; DU4= natural pasture hay $+400 \mathrm{sg}$ wild silver leaf Desmodium.

Digestible CP intake was higher $(\mathrm{P}<0.001)$ in the order of DU-400g $>$ DU-300g $>$ DU-200g $>$ DU-0. The nutrient requirement of growing animals changes throughout the growing periods in direct response to the changing needs of the individual organs and organ systems making up the whole animal (Pond et al., 1995). During the first ten days of the feeding trial, the daily DM intake of silver leaf desmodium reached maximum after which intake slightly increased in DU-200g, DU-300 and DU-400g throughout the experiment. However, DM intake in DU-0 progressively increased over the period of the experiment. Similar trend in DM intake was observed by Jaques et al. (1994) in which the daily hay DM intake of sheep fed only hay decreased for the first two weeks and then gradually increased.

\section{Dry Matter and Nutrient Digestibility}

Table 4 shows dry matter and nutrient digestibility of Horro Sheep fed natural pasture hay and graded levels of wild silver leaf desmodium. The supplemented sheep groups had significantly higher $(\mathrm{P}<0.05)$ dry matter and crude protein digestibility than the other treatments, but there was no significant difference between DU_ $200 \mathrm{~g}$ and DU_300g. Organic matter, NDF, and ADF digestibility increased $(\mathrm{P}<0.001)$ with increasing level of desmodium supplementation. The result of the current study showed that supplementation with legume hay improved digestibility of the natural pasture hay, thus overall nutrient digestibility.

The lower digestibility of nutrients in the control than the legume hay supplemented treatment groups is due to the lower $\mathrm{CP}$ and higher ADF content of the hay basal diet, which affected nutrient digestibility. Increasing the amount of dietary CP content was reported to increase the digestibility of low quality hay (Ranjhan, 1997). The observed higher digestibility of CP of the legume supplemented natural pasture hay diets may be attributed to the substantial improvement in the rumen microbial activity, especially that of cellulolytic organisms, (Osuji et al., 1995; Umunna et al., 1995; Topps, 199) and higher fragility of the cell-walls of the legume supplemented diets (McBurney et al., 1986).

Higher CP digestibility obtained in the present experiment is in agreement with the reports of Wondwosen (2008) who observed that supplementation increased CP digestibility. Simret (2005) also reported that peanut and wheat bran supplementation improved the digestibility of CP in Somali goats fed basal diet of natural pasture hay. Amansisa (2010) reported increased apparent digestibility coefficients of nutrients in Horro sheep fed natural pasture hay basal diet and supplemented with different levels of dried $V$. amygdalina foliages and crushed maize grain. 
Table Apparent digestibility coefficients of dry matter and nutrients in Horro sheep fed natural pasture hay basal diet and graded level of wild silver leaf desmodium

\begin{tabular}{llllllc}
\hline Parameter & DU-0 & DU-200g & DU-300g & DU-400g & SEM & SL \\
\hline DM & $0.48^{\mathrm{c}}$ & $0.68^{\mathrm{b}}$ & $0.72^{\mathrm{b}}$ & $0.80^{\mathrm{a}}$ & 0.009 & $* * *$ \\
$\mathrm{OM}$ & $0.48^{\mathrm{d}}$ & $0.70^{\mathrm{c}}$ & $0.74^{\mathrm{b}}$ & $0.82^{\mathrm{a}}$ & 0.001 & $* * *$ \\
$\mathrm{CP}$ & $0.84^{\mathrm{c}}$ & $0.88^{\mathrm{b}}$ & $0.88^{\mathrm{b}}$ & $0.91^{\mathrm{a}}$ & 0.005 & $* * *$ \\
$\mathrm{NDF}$ & $0.36^{\mathrm{d}}$ & $0.64^{\mathrm{c}}$ & $0.68^{\mathrm{b}}$ & $0.78^{\mathrm{a}}$ & 0.003 & $* * *$ \\
$\mathrm{ADF}$ & $0.19^{\mathrm{d}}$ & $\mathrm{O} .45^{\mathrm{c}}$ & $0.54^{\mathrm{b}}$ & $0.69^{\mathrm{a}}$ & 0.002 & $* * *$ \\
\hline a b,c,d= Means within a row not bearing a common superscript letter are significantly different $; *=P<0.5 ; * * *=$
\end{tabular}
$(p<0.001) ; A D F=$ Acid detergent fiber; $C P=$ Crude protein; $D M=$ Dry matter'; NDF = Neutral detergent fiber; $O M=$ Organic matter; SEM = standard error of mean; $S L=$ significant level; $D U 1=$ natural pasture hay ad libitum; DU2= natural pasture hay ad libitum $+200 \mathrm{~g}$ wild silver leaf Desmodium; DU3= natural pasture hay ad libitum $+300 \mathrm{~g}$ wild silver leaf Desmodium; DU4= natural pasture hay ad libitum $+400 \mathrm{~g}$ wild silver leaf Desmodium.

\section{CONCLUSIONS}

Generally, the results of the study explicitly confirmed the advantages of supplementation of legumes in improving feed intake, nutrient digestibility and nutrient utilization than feeding sole natural pasture hay due to better availability of nutrients to animals' particularly crude protein.

Therefore, supplementation with $400 \mathrm{~g}$ /day desmodium hay higher improved feed intake and digestibility of sheep. Hence, in the present study, it was concluded that supplementation of hay with $400 \mathrm{~g} / \mathrm{day} / \mathrm{head}$ is biologically efficient and potentially profitable in feeding of growing Horro sheep.

\section{ACKNOWLEDGEMENTS}

First and foremost, I would like to provide thanks to the Almighty God for the blessing and supplying strength, believes, love, hope, patience and protection to me and my families throughout my life.

\section{REFERENCES}

Amansisa Eresso(2010) Effect OF supplementation of different levels of dried 'girawa' (Vernonia amygdalina) foliage and crushed maize grain mixtures on feed intake, digestibility and body weight change Horro sheep feed a basal diet natural pasture hay.

CSA (Central Statistics Authority), 2004. Ethiopian agricultural sample enumeration. Result at Country level. Central Stastics Authority, Addis Ababa, Ethiopia. pp. 222-232

CSA (Central statistical agency(2012/13); federal democratic republic of Ethiopia central statistical agency agricultural sample survey volume II report on livestock and livestock characteristics 2012/13 [2005 E.C.]

Devendra, C. and M. Burns, 1983. Feeding and nutrition. In: Goat production in the tropics. CAB (Commonwealth Agricultural Bureaux), Famham Royal, Slough, VK.pp.90-115.

FAO (Food and Agricultural Organization),2000. Hay and straw conservation for small scale Farming and pastoral condition: hay making in Ethiopia. Prepared by Suttie J.M. (FAO Plant Production and Health Series, No.29.) Rome, Italy.

Fentie Bishaw, 2007. Feed utilization and live weight change of Farta Sheep Supplemented with noug seed (Guizotia abyssinica) cake, wheat bran and their mixtures. An MSc Thesis presented to the School of Graduate Studies of Haramaya University. 87p

Kibrom Tafere and Ibrahim Worku (2012); Consumption Patterns of Livestock Products in Ethiopia: Elasticity Estimates Using HICES (2004/05) Data

Markos Tibbo, 2006. Productivity and health of indigenous sheep breeds and crossbreds in the Central Ethiopian Highlands. Doctoral Thesis. Swedish University of Agricultural Science, Department of Animal Breeding and Genetics. Uppsala, Swedin. 11pp

McBurney, M.M. S. Allen and P. J.Van Soest, 1986. Praseodymium and copper action exchange capacities of neutral detergent fibres relative to composition and fermentation kinetics. Journal of the Science of Food and Agriculture 37:666-672

Mulu Moges, Berehan Tamir and Alemu Yami, 2008. The effect of Grass Hay with different level of Brewer's Dried Grain on feed intake, digestibility and body weight gain intact Wogera lumbs. East African J. of Sci. Vol.2, Num.2. June 2008. Issn 1992-0407, pp 105-110.

Mulu Moges, 2005. Effects of feeding different levels of breweries dried grain on live weight gain and carcass characteristics of Wogera Sheep fed on hay basal diet. MSc. Thesis Presented to School of Graduate Studies, Haramaya University. 54p Pond,W.G.DC. Church Topps, J.H., 1995. Forage legumes as protein supplements to poor quality diets in the semiarid

Osuji, P.O.S. Femandez-Rivera, A.Odenyo, 1995. Improving fiber utilization and protein Supply in animals fed 
poor quality roughages: ILRI nutrition research plans. Tropics. In:

Singh,G.P. and S.J.Oosting, 1992. A model for describing the energy value of straws. Indian Dairyman XLI: 322-327

Simachew Gashaw, 2009. Effects of Supplementation with maize bran, Noug seed (Guizoitia abyssinica) cake and their mixtures on feed utilization and carcass characteristics of Washera sheep fed hay. An MSc Thesis presented to the School of Graduate Studies of Haramaya University. 25-26pp

Sollenberger, L.C.C.S.J.R. Jones, K.A.Albrecht, and G.H.Ruitenberg, 1990. Vegetative establishment of Dwarf elephant grass. Effects of defoliation prior to planting stems. Agroon. J. 82(2):278

Solomon Abegaz 1996. Performances of ewes lambing at two different periods of rainy season.

Pp. 86-92. Proceedings of the 4 th National Conference of Ethiopian Society of Animal eduction (ESAP). Addis Ababa, Ethiopia, 18-19 April1996

Seyoum Bediye and Zinash Sileshi, 1995b. Influence of variety and location on feeding value of barley straw. Pp. 312-315. In: Proceedings of the 3rd Annual Conference of the Ethiopian Society of Animal Production (ESAP) held in Addis Ababa, Ethiopia. 27-29 April 1995. ESAP

Tessema, Zewdu and.Halima H.1998. Forage and pasture research achievements in northwestern

Ethiopia. In: Seboka, B.A.Deressa (Eds.), Procceedings of the fourth technology generation. Transfer and gap analysis workshop on agricultural research and technology transfer attempts and achievements in northern Ethiopia. 18-21 March 1997, Bahir Dar, Ethiopia. Umunna, N.N., P.O. Osuji, I.V. Nsahlai, H. Khalili and A.M. Mohamed-Saleem, 1995.

Umunna, N. N, P.O. Osuji, I V.Nsahlai, H. Khalili and M.A. Mohamed-Saleem, 1995.Effect of supplementing oat hay with lablab, sesbania, tagasaste and wheat middlings on voluntary intake, $\mathrm{N}$ utilization and weight gain of Ethiopian Menz sheep. Small Ruminant Research 18 (2): 113-120., and K.R.POND 1995. Basic animal nutrition and feeding. $4^{\text {th }}$ (ed).John wiley \&s ones, New York.

Van Soest, P.J.1982. Nutritional ecology of the ruminant.O and B books. Corvallis, Oregon

Van Soest, P.J., 1982. Nutritional ecology of the ruminant.O and B books. Corvallis, Oregon.

Wondwosen Alemu, 2008. Effect of supplementing hay from natural pasture with oil seed cakes on feed intake, digestibility and live weight change of Sidama goats. A MSc. Thesis Presented to School of Graduate Studies, Haramaya University, Ethiopia. 27p.

Wondwosen Alemu, 2008. Effects of Supplementing hay from natural pasture with oilseed cakes on feed intake, digestibility and body weight change of Sidama goats. An MSc Thesis presented to the School of Graduate Studies of Haramaya University, Ethiopia. 62p

Zelalem Alemayehu and IFletcher, 1991. Small ruminant productivity in the central Ethiopian mixed farming system. Pp. 45-70. In: Proceeding of the 4th National Livestock Improvement Conference (ESAP), 13-15 November. Addis Ababa, Ethiopia.

Zelalem, Alemayehu. And Fletcher, I.C. 1991. Small ruminant productivity in central Ethiopian highlands mixed farming systems. In: IAR Proceedings of fourth Livestock improvement conference held in Addis Ababa, 13- 15 November 1991. IAR (Institute of Agricultural Research), Addis Ababa 